\title{
Eco-crimes and Ecocide at Sea: Toward a new blue criminology
}

Ascensión García Ruiz ${ }^{1}$, Nigel South ${ }^{2}$ and Avi Brisman ${ }^{3}$

International Journal of Offender Therapy and Comparative Criminology 2020/21

\section{Abstract}

This essay adopts an interdisciplinary approach to consider the meaning of 'eco-crime' in the aquatic environment and draws on marine science, the study of criminal law and environmental law, and the criminology of environmental harms. It reviews examples of actions and behaviours of concern, such as offences committed by transnational organised crime and the legal and illegal over-exploitation of marine resources, and it discusses responses related to protection, prosecution and punishment, including proposals for an internationally accepted and enforced law of ecocide. One key element of the policy and practice of ending ecocide is the call to prioritise the adoption of technologies that are benign and renewable. Our essay concludes with a description of the 'Almadraba' method of fishing to illustrate that there are ways in which the principles of sustainability and restoration can be applied in an ethical and just way in the context of modern fisheries.

\section{Keywords}

Almadraba; blue criminology; ecocide; green criminology; illegal, unreported and unregulated fishing (IUU); transnational organised crime

\footnotetext{
${ }^{1}$ Assistant Lecturer. Department of Criminal Law and Criminology, Faculty of Law, Spanish University for Distance Education (UNED) Madrid (Spain). ORCID: https://orcid.org/0000-0003-1425-0409 (Corresponding author).

2 Professor, Department of Sociology, University of Essex, Colchester, UK; Adjunct Professor, School of Justice, Faculty of Law, Queensland University of Technology, Brisbane, QLD, Australia. ORCID: https://orcid.org/0000$\underline{0001-5742-7257}$

${ }^{3}$ Professor, School of Justice Studies, College of Justice and Safety, Eastern Kentucky University, Richmond, KY, USA; Adjunct Professor, School of Justice, Faculty of Law, Queensland University of Technology, Brisbane, QLD, Australia; Conjoint Professor, Newcastle Law School, Faculty of Business and Law, University of Newcastle, Callaghan, NSW, Australia. ORCID: https://orcid.org/0000-0001-5794-0210
} 


\section{1. Introduction}

The challenges associated with what we can call 'eco-crimes' are growing. 'Humanity's self-ordained mandate to subdue and dominate nature', as Bearzi (2020) puts it, has affected the planet so much that it is, arguably, entering a new geological epoch-the Anthropocene

5 (Brisman \& South 2018). These actions and effects occur across a wide variety of locations

6 and the resulting impacts may materialise far from their source, in terrestrial, atmospheric or 7 aquatic ecosystems (Zalasiewicz et al. 2019). Referring to the vital role that recognition of the 8 Anthropocene will play in the context of international law, Vidas (2015: 2) remarks that it 'will 9 bring a fundamental shift ... in which the challenges are increasingly recognized as the consequences of natural, not only political, change'. This factor may exacerbate already

11 'existing tensions in the regulation of inter-state relations under international law', and present serious challenges to fledgling international environmental criminal law. Despite the well-documented state of the planet-the degradation of land, destruction of forests, pollution of air, and endangerment of the seas and aquatic life-political and popular opinion and action have, for various reasons, not addressed the challenges with the urgency they deserve (South 2016; see also Klein 2019).

In this essay, we consider the case of the world's seas, often overlooked in comparison to the attention paid to air quality or loss of forests due to wildfires and agricultural clearance

19 (see Sheppard 2019). Jouffray and colleagues (2020: 46) refer to the increasing human pressures now being placed on the worlds' oceans as 'the blue acceleration', noting that while human claims to marine 'resources', such as for food and materials, are not new, 'the extent, intensity, and diversity of today's aspirations are unprecedented'. Crimes and harms affecting the marine environment might, we suggest, be considered as part of a new 'blue criminology' which embraces, for example, the concept of transnational organised crime at sea which can 
1 be found in operation in differing ways across the world's maritime regions (see generally

2 Paulson 2018). Bueger and Edmunds (2020) identify three focal categories of relevance here:

3 crimes against mobility (modern piracy, cybercrime), criminal flows or transit crime

4 (smuggling, human trafficking), and environmental crimes (e.g., fishing, waste dumping at

5 sea, unregulated activities). To consider all these together suggests the need for international

6 criminal law that is holistic and that can provide the basis for a comprehensive response. Today, the social and natural sciences need to be more sophisticated, without being more compartmentalized: in other words, they need to be intellectually receptive and

9 sympathetic to each other in order to synthesize useful knowledge regarding environmental

10 threats (see Bearzi 2020). Adopting an interdisciplinary approach to findings from marine

11 science opens a window of opportunity for the study of criminal law, and for a criminology

12 concerned with environmental harms to consider the meaning of 'blue crime' and possible

13 interventions (Bueger \& Edmunds 2020). Both the criminology of the environment-referred

14 to as 'green criminology' (Brisman \& South 2019b, 2020)-and environmental criminal law

15 (Boyle 2012, García Ruiz 2017, Sands et al. 2018, Junker 2019)-have played increasingly

16 important and thought-provoking roles in their disciplines. A 'green' perspective in

17 criminology has extended the field and dissemination of its arguments to different audiences

18 far from the limitations of orthodox criminology (South 1998, see also Lynch et al. 2017), while

19 environmental law has often sought to push international and national law in new directions

20 and to make connections with rights discourses, victim's movements and environmental 21 campaigns.

Green criminological studies are focused on not only acts and omissions defined as

23 'crimes' under the law, but also legally perpetrated harm (South 2014). As such, green 24 criminologists have a spectrum of activities and consequences to explore (for an overview of 
1 causes, responses, prevention and meaning of eco-crime or environmental crime and harm

2 and their eco-philosophical alignments, see Brisman \& South 2019b, 2020). The range of

3 manifestations of eco-crimes/harms at sea could embrace, among other examples: illegal

4 shipping and marine piracy, both of which involve blatant disregard for national, regional and

5 international environmental law (e.g., Collins 2015, Bueger \& Edmunds 2020); illegal fishing,

6 which competes with traditional fisheries, destroys sea-bottom ecosystems, and aggravates

7 tensions over vessel licensing (Belhabib \& Le Billon 2020: 1); massive extraction of mineral

8 and metal resources from seawater, involving companies engaging in fracking offshore and

9 dumping toxic chemicals into the ocean (Jouffray et al. 2020); depletion of mangrove

10 ecosystems and salt marshes, which are increasingly threatened by direct and indirect human

11 activities, or by the effects of climate change (WWF 2020, see also Cohen 2018, Lavaniegos

12 2018, Pierre-Louis and Popovich 2019, Smale et al. 2019); discharges of waste in ocean waters

13 (Greife and Stretesky 2013, see also Taylor 2019); the impact of light pollution (artificial light)

14 on marine fish and zooplankton in an increasingly warmer Arctic (Berg et al. 2020, Gibbens

15 2020); and 'ghost fishing' caused by abandonment or dumping of fishing gear in the oceans

16 (Brown \& Macfayden 2007, Leschin-Hoar 2016).

17 The response of criminal law and legislation is far from homogeneous at the

18 international level and policy is often centred more on human environmental actions and

19 impacts than on advancing 'rights' of oceans, seas or aquatic life (see Brisman 2014a). In other

20 words, diverse impacts are met with disparate responses.

The discussion here is wide-ranging but focused on the waters of the oceans and seas

22 and their adjacent zones. (For a review of challenges relating to fresh water sources and

23 systems, see Brisman et al. 2018.) The aim is to provide the basis for facilitating the design

24 and adoption of appropriate, new or improved, regulations, norms and behaviours to protect 
ecosystems, human and non-human animals (Brisman 2014b), as well as the biosphere per se

2 (Brisman \& South 2019b). There is an urgency about doing this. Politics can be populist and

3 poorly informed, and law-making can be slow and conservative; both can be 'opportunistic

acknowledgement of the benefits of traditional forms of engagement with the environment that have valued stewardship, as well as recognition of the long-term consequences of poordecision making.

In the sections that follow, we review examples of the kind of actions and behaviours

9 that are of concern to green criminology and environmental law, such as organised crime offences and the legal and illegal over-exploitation of marine resources. We then turn to the matter of responses and issues related to protection, prosecution and punishment. One of the most powerful propositions that has been made in relation to these responses is that there should be an internationally accepted and enforced law of ecocide and this is outlined next. Calling for the end of ecocide is for the benefit of the planet, its ecosystems and all those beings that depend on them, and it is timely given threats like climate change, pollution and the pressures on the land and the sea as sources of food production. One key element of the policy and practice of ending ecocide is the call to prioritise the adoption of technologies that are benign and renewable on a global basis (Higgins et al. 2013: 263). We therefore conclude our essay with a description of the 'Almadraba' method of fishing to illustrate that there are ways in which the principles of sustainability, restoration and control over the depletion of certain species, can be applied in the context of modern fisheries.

\footnotetext{
${ }^{4}$ We omit an examination here of the effects of civil or administrative sanctions because these are limited geographically, with varying macro-level impacts. Our approach would, therefore, view the concept of 'ecocide' (discussed further below) as one to be applied to the sea/ocean globally and would also consider international criminal law as a primary method of prevention (without denying the value of dialogue with other branches of law). For a related discussion on international criminal law, prevention and wildlife crime, see Nurse (2015).
} 


\section{2. Eco-organised crime at sea}

'Eco-crime' is a term that can be applied to the activities of various organised groups operating at multiple environmental sites (Walters 2014, see also Collins 2015, Fajardo 2015, Sergi \& South 2016, Gore et al. 2019). Some of the most damaging eco-crime categories involve a transnational dimension-such as working across borders or in international waters

6 to dispose of toxic waste, discharge oil and garbage from ships illegally, or engage in illegal

7 fishing outside of regulatory controls designed to protect at-risk species (Bondaroff et al.

8 2015, Haenlein 2017, Bueger \& Edmunds 2020). According to Belhabib and Le Billon (2020:

9 1), '[t]he criminal dimensions of illegal fishing include both fisheries related crimes such as

10 enforcement evasion, misreporting, document forging, money laundering, labor abuses, and

11 tax evasion [...] but also crimes associated with the fisheries sector, including piracy (Denton

12 \& Harris 2019) and various types of trafficking' (UNODC 2011; Vrancken et al. 2019). An

13 additional complication here is that criminal agents are often working with, or taking

14 advantage of, institutional bodies and practices engaged in legal activities in the market

15 (Ruggiero \& South 2010, Ruggiero 2013, White 2017).

16 The commission of serious offences at sea occurs, in part, because they can be highly

17 lucrative-as profitable as illegal drug trafficking or smuggling. For example, as a study

18 conducted by the United Nations Office on Drugs and Crime (UNODC) (2011: 127) concluded,

19 'marine living resources have become a high profit, low risk target for criminals [...] Typically,

20 marine living resource crimes are offences against marine living resource management and conservation regulations. A number of States regard marine living resource crimes as the predicate offences of up- and downstream crimes such as money laundering, corruption, handling of stolen goods and tax- and customs fraud'. In addition, such crimes are often hard to detect and, when offenders are apprehended and prosecuted, sanctions are lower than for 
1 some less serious crimes. Generally, then, the majority of such criminal actions go

2 unpunished; when punishment is imposed, the focus is often on determining financial liability

3 and imposing pecuniary fines rather than on sentencing individuals to a prison term, which

4 could possibly play a more dissuasive and preventive role for states and large corporations.

5 Detection is not impossible of course and, notably, a recent global law enforcement operation

6 involving environmental, maritime and border agencies, as well as national police, customs,

7 and port authorities across sixty-one countries, did identify thousands of illicit activities,

8 including severe marine pollution and serious cases of contamination worldwide (Europol

$92019 b$, Interpol 2019) $)^{5}$. We discuss issues of protection, prosecution and punishment further

10 below.

\section{3. Crimes and harms of overexploitation of marine resources}

The Common Fisheries Policy is the statement of European Union (EU) rules designed

14 to combat illegal, unreported and unregulated fishing (IUU), to manage European fishing

15 fleets, and to conserve fish stocks (the most recent update took effect on 1 January 2014).

16 IUU fishing practices generate enormous profits every year worldwide. Indeed, they generate

17 massive flows of 'dirty money', which remains outside financial and tax control. Therefore,

18 such activities represent a pattern of activity closer to the profile of an 'organised criminal

19 industry' (UNODC 2011, 2017), further increasing the threat of extinction to species, with the

20 largely irreversible and harmful ecological consequences extinction entails (Dayton et al.

21 1995; see also Brisman \& South 2019a, Kolbert 2019). Moreover, older and more polluting

\footnotetext{
${ }^{5}$ As one example of an illegal market based on smuggling, the fishing season in 2018-19 was particularly profitable for the business of smuggling glass eels: European law enforcement was able to seize 5,789 eels with a market value of $€ 2000$ per kilo. According to Europol, criminal organisations may have made more than $€ 6$ million a year from this illegal transnational operation.
} 
1 vessels employed by some IUU fishers have a greater impact on the environment than other

2 vessels (Bondaroff et al. 2015: 17).

3

Pauly and Zeller (2016) have analysed data to produce estimates regarding global marine fisheries catches. Using a decade-long, multinational 'catch reconstruction'

5 methodology, covering the Exclusive Economic Zones (EEZ) of the world's maritime countries

6 from 1950 to 2010, and accounting for all fisheries, they point out an urgent need for

7 improved monitoring of all fisheries, including often neglected small-scale fisheries, and

8 illegal and other problematic fisheries, as well as discarded bycatch. The authors reach their

9 'urgent' conclusion because, based on the reconstructed data, overall, catches are $53 \%$ higher

10 than the data reported by the Food and Agriculture Organization (FAO) on behalf of its

11 member countries (Pauly \& Zeller 2016: 3; see also the Ecopath modelling approach and

12 software http://sirs.agrocampus-ouest.fr/EcoBase/ and FishBase, the online encyclopedia of

13 fishes www.fishbase.org complemented recently by SeaLifeBase www.sealifebase.org). The

14 argument is that monitoring can have an effect. After the International Commission for the

15 Conservation of Atlantic Tunas (ICCAT)-an inter-governmental fishery organization

16 responsible for the conservation of tunas and tuna-like species in the Atlantic Ocean and its

17 adjacent seas (https://www.iccat.int/en/)-launched requirements for statistical

18 documentation schemes, the amount of unreported tuna catch decreased significantly in the

19 Central Atlantic. The decline of illegal fishing in the Western Indian Ocean also reflects the

20 gradual increase in control over time by coastal states (Agnew et al. 2009: 3). This partial

21 international control is not sufficient, however, to deal with the context of burgeoning

22 demand for food and particularly protein', which will continue to place enormous pressure

23 on fish stocks over the next 50 years (Agnew et al. 2009: 5, see also Costello et al. 2020). As

24 just one indicator, the demand for tuna and tuna-like species seems to be currently at an all- 
1 time high (Greenberg 2010, Coulter et al. 2020). In addition, a serious threat to various

2 endangered small cetaceans comes from small-scale fisheries responding to growing demand

3 for domestic consumption rather than for export. The rise in fishing activity, then, creates

4 further dangers as discard of tackle and fishing nets can lead to entangling larger species, such

5 as sperm whales, which has occurred in the Mediterranean Sea (Brown \& Macfayden 2007,

6 Leschin-Hoar 2016, Staff 2020). Brownell and colleagues have suggested that the definitive

7 long-term solution to this is the use of 'efficient, inexpensive, alternative fishing gear that can

8 replace gillnets without jeopardizing the livelihoods of fishermen' (2019: 293). We return to

9 the possibilities of long-term benefits offered by small-scale fishing later.

11 4. Lack of uniformity of protection, prosecution and punishment regarding eco-crimes at sea

Protected areas in marine and coastal areas might be described as any one of the

14 following: marine conservation area, marine management area, marine monument, marine park, marine reserve, marine refugia, marine sanctuary, or marine wilderness area. These terms may carry different implications or expectations regarding protections in place and often the activities that are permitted and exempt from protective restrictions will be dissimilar and depend on the country administering such zones (Dudley et al. 2008, 2013: 5559, Laffoley et al. 2019). Possibly the most common nomenclature internationally is 'Marine Protected Area' (MPA). Over 70\% of the surface of the Earth is ocean, comprised of highly diverse ecosystems, and providing a wide range of marine ecosystem services that support human society, health and the economy, but only $7.91 \%$ of this is designated as MPAs and

23 fewer than $10 \%$ of such areas achieve their management goals and objectives (UNEP-WCMC 
1 most pressing issues regarding the prevention of overexploitation of species (Sosa-Nunez

2 2018: 4, see also Cohen 2018, Rodríguez-Rodríguez 2019: 480). As Bearzi (2020) reminds us,

3 however, human impact may increase within MPAs if management permits certain actions to

4 continue (such as overfishing or high-intensity noise from oil and gas exploration). Moreover,

5 MPAs cannot fully prevent other important pressures damaging to marine life, such as water

6 pollution. In other cases, such as over-exploitation, as Belhabib and Le Billon (2020:2) argue,

7 '[a]uthorities should not simply respond to illegal fishing through fishery management, but

8 address its many transnational criminal dimensions'. Correspondingly, Jouffray and

9 colleagues (2020: 48) observe that the 'once-popular view that the ocean-unlike the

10 continents - was simply too big to be affected by human actions has been replaced by the

11 reality of the Anthropocene Ocean (Levin \& Poe 2017), in which the ocean is neither "too big

12 to fail nor too big to fix, it is too big to ignore" (Lubchenco \& Gaines 2019)', and today,

13 'addressing the diversity of claims, their impacts, and their interactions, will require effective

14 governance'.

Such governance would ideally reflect the global 'common interest' (Hardin 1968, see

16 also Brisman 2003) but, at present, the 'sharing' that is implied in the idea of 'the commons'

17 has been undermined and lost support. Indeed, although the oceans are global, in law they

18 are divided into areas, either subject to national jurisdiction-national waters-or areas

19 beyond national jurisdiction (ABNJ)-international waters-an arrangement which means

20 national jurisdictional bodies are generally (and formally) incapable of prosecuting and

21 judging most transnational criminal activities happening at sea. Such limited jurisdictions also

22 signify that each coastal state holds certain exclusive rights over their own EEZ and the

23 continental shelf, which extends for up to 200 nautical miles out from the coastal baseline

24 (Schiffman 2018). The outer limits of any EEZ should mark the start of international waters, 
1 where any state has the right to freedom of navigation, freedom of fishing, and freedom to

2 pursue scientific marine research (Orbach 2003). In recent years, however, a phenomenon

3 that Jouffray and colleagues (2020: 46) refer to as 'seabed grabbing' has seen an increasing number of states lay claims to extended continental shelf territories with degrees of overlap

5 (see, e.g., Chivers 2007, Parfitt 2007, Reuters 2007). This, they argue, is 'not only transforming

6 the geopolitical landscape'-or seascape-but 'also substantially shrinking the area

7 designated as the common heritage of humankind' (Jouffray et al. 2020: 46).

9 the oceans, the current picture of international law of the sea presents a tapestry of national and international rules, customs, treaties, and agreements. These complement the important

11 United Nations Convention on the Law of the Sea (UNCLOS), adopted in 1982-the so-called

12 'Constitution for the Seas' - that continues to be the primary international treaty (see

13 Brisman 2011, Schiffman 2018) $)^{6}$. The formalization of UNCLOS was a watershed moment in

14 ending centuries of legal freedom to navigate the ocean (the concept of mare liberum) and moving towards its territorialization (as epitomized by the concept of mare clausum) (Russ \&

16 Zeller 2003).

\footnotetext{
${ }^{6}$ The foremost international and European legislation on the issue-among other bilateral agreements and regional initiatives-are (in chronological order) as follows: International Convention for the Regulation of Whaling 1946; International Convention for the Prevention of Pollution of the Sea by Oil 1954; International Convention on Civil Liability for Oil Pollution Damage 1969; Convention on the Prevention of Marine Pollution by Dumping of Wastes and Other Matter 1972; Protocol to the International Convention on Civil Liability for Oil Pollution Damage 1976; International Convention for the Prevention of Pollution from Ships 1976, as modified by the Protocol of 1978 (MARPOL); International Convention for the Safety of Life at Sea 1974 (SOLAS); International Convention on Oil Pollution Preparedness, Response and Cooperation 1990 (OPRC); International Convention on Liability and Compensation for Damage in Connection with the Carriage of Hazardous and Noxious Substances (HNS) by Sea 1996; International Convention on the Control of Harmful Anti-fouling Systems on Ships 2001; Convention on the Conservation and Management of Highly Migratory Fish Stocks in the Western and Central Pacific Ocean 2000; Environmental Liability Directive 2004/35/EC; Marine Strategy Framework Directive 2008/56/EC; Council Directive 92/43/EEC of 21 May 1992 on the Conservation of Natural Habitats and of Wild Fauna and Flora; Directive 2009/147/EC of the European Parliament and of the Council of 30 November 2009 on the Conservation of Wild Birds. For an overview of some of these instruments, see Schiffman (2018:6673).
} 
UNCLOS has not resolved all questions of oceanic ownership, however. At present, for

example, relevant procedural and substantive issues are the subject of energetic discussions in relation to the rights of certain nations to articulate claims on the wealth of mineral resources from the Arctic. This has become a case that some parties have wished to press with increasing urgency as the Arctic sea ice retracts, making access to the natural resources of the region more accessible than ever before (Brisman 2013, Sun \& Beckman, 2018, Berg et al. 2020, Gibbens 2020).

In this regard, compliance with the International Code for Ships Operating in Polar Waters (Polar Code) of the International Maritime Organisation (IMO), which entered into force in 2017, is mandatory under both the International Convention for the Safety of Life at Sea (SOLAS) and the International Convention for the Prevention of Pollution from Ships (MARPOL). The Polar Code covers the full range of construction, design, equipment, operation, search and rescue, and training, as well as environmental protection matters, relevant to ships operating in the waters surrounding the two poles. The question, however, is whether the Polar Code provides the basis for sufficient protection and effective regulation to minimize the likely pollution from increased shipping in this striking marine environment and manage potential threats, such as heavy grade oil use and disposal, ballast water discharge, and anti-fouling requirements (Nengye 2016).

The aim of protecting oceans and seas and promoting the sustainable use of marine resources has been developed mainly through the 'Regional Seas Programme' of the United Nations Environment Programme (UNEP) - the leading global environmental authority. UNEP also created the Global Programme of Action for the Protection of the Marine Environment from Land-based Activities. Together, Regional Seas Conventions and Action Plans represent the world's only legal framework for protecting the oceans and seas at the regional level. 
1 These global intergovernmental mechanisms address directly the nexus between terrestrial,

2 freshwater, coastal and marine ecosystems. In addition, in 2016, the European Commission

3 and the EU's High Representative set out a joint agenda for the future, proposing fifty actions

4 for safe, secure, clean and sustainably managed oceans in Europe and around the world (see

5 'International ocean governance: an agenda for the future of our oceans in the context of the

62030 SDGs' and the Joint Report to the European Parliament and the Council 'Improving

7 International Ocean Governance-Two years of progress' \{SWD (2019) 104 final\}, Brussels,

8 15.3.2019). As Brownell and colleagues (2019: 293) observe, 'institutions with the

9 responsibility, legal authority, expertise, and resources to pursue conservation as a top

10 priority' can help to meet these goals, 'particularly if local communities are involved in a

11 manner that rewards and reinforces their commitment', although the legal framework to

12 accomplish this often awaits further reforms coupled with the enactment of technically

13 suitable environmental laws (see for example, the report on adaptation of EU Directive

$142008 / 99 / E C$ on the protection of the environment through criminal law into the Portuguese-

15 Spanish criminal arena: Fuentes Osorio et al. 2020).

16 Forthcoming responses to address global blue governance still seem to be weak and

17 underdeveloped, although in 2019, the UN did present proposals for the 2020 United Nations

18 Conference to Support the Implementation of Sustainable Development Goal 14: Conserve

19 and sustainably use the oceans, seas and marine resources for sustainable development.

20 Naturally, due to the Covid-19 pandemic, this planned conference has been postponed sine 21 die (GA decision $74 / 548)^{7}$.

\footnotetext{
${ }^{7}$ A/RES/73/292. Resolution adopted by the General Assembly on 9 May 2019. UN Ocean Conference: 'Save our Ocean, Protect our Future'. Lisbon, Portugal 2020: https://www.un.org/en/conferences/ocean2020
} 

acknowledge each state's sovereignty, i.e., each nation's environmental criminal law rules,

3 but national case law and campaigns can also help to influence and shape international law.

4 National and international law are mutually influential, for example within the context of 5 European criminal law. Some of the most important developments in marine pollution legislation have been triggered by large-scale maritime catastrophes, such as the cases of the 'Erika' (Giovannini et al. 2013) or the 'Prestige' (Frank 2005, Penela-Arenaz et al. 2009, García Ruiz 2014). The

9 Mattese tanker 'Erika', sank off the coast of Brittany (France) in 1999, eventually broke in two parts carrying about 30, 000 tonnes of heavy fuel oil and as a result, 14,000 tonnes of oil were spilled. The pollution stretched along more than 100 miles of the Atlantic coastline. A Panama

12 branch of the French company, 'Total International Ltd.', owned the cargo and the final 13 judgement, which was far from exemplary but could not be appealed, ruled that the company 14 was guilty only of negligence (Giovannini et al. 2013: 29). In 2002, the catastrophic oil-spill caused by the break up and sinking of a different 16 ship, the 'Prestige', that was in poor structural condition, caused the Galician coastline (Spain) 17 to suffer an ecological and economic tragedy of unprecedented proportions. The subsequent 18 investigations highlighted the difficulties involved in determining who might be held 19 responsible for the oil spill because the Prestige was officially registered in the Bahamas. Both 20 the Spanish oil company Repsol-since 1997-and the British company BP (formerly British 21 Petroleum) - since 2000-had previously rejected use of the ship for several reasons: its age, 22 problem with its documentation, and absence of a CAP (Condition Assessment Program)

23 (García Ruiz 2014). Despite these and many other repeated experiences, such as the recent 24 oil spill in the Indian Ocean near Mauritius from the Japanese vessel MV Wakashio (Bueger 
$12020)$, the global legal system continues to tolerate 'an organized irresponsibility model which

2 benefits major polluters' (Baucells \& Petit 2013: 5).

3

As Bennet and colleagues (2019: 991) note, 'Policy frameworks and environmental assessment processes to adequately understand and manage the environmental risks of maritime development are nascent or often do not yet exist'. We attempt to illustrate aspects of this dynamic and some possible responses in the next section.

\section{Ecocide at sea}

In general, 'ecocide' is described as 'the extensive damage to, destruction of or loss of ecosystem(s) of a given territory, whether by human agency or by other causes to such an extent that peaceful enjoyment by the inhabitants-human and non-human-of that territory has been severely diminished' (Higgins 2015: 63). For Higgins, because 'territory' represents an 'open' concept, maritime extensions should also be included. Of course, 'ecocide' is not yet recognized internationally as a 'crime', and the International Criminal Court (ICC) remains the single competent judicial authority to prosecute individuals for international crimes of genocide, crimes against humanity, crimes of aggression, and war crimes, as set out by the Rome Statute (RS), in force from 1 July 2002 (for an overview and explanation why the initiative to include 'ecocide' in the Rome Statute failed, see Gauger et al. 2012, Higgins et al. 2013, Higgins 2015, García Ruiz 2018). Although ecocide has not yet been incorporated into international law, it has been defined by several authors, such as Berat (1993), Falk (1973) and Gray (1996), who had formulated conceptual descriptions preceding Higgins' definition (García Ruiz 2018: 6). The amendment of the Rome Statute presented by Higgins to the United Nations Law Commission in 2010 was aimed at pushing for the enactment of an 'Ecocide Act' within the jurisdiction of the ICC. To date, however, this 
1 proposal for an international law designating ecocide as a crime represents only a proposal

2 de lege ferenda-with a view to future law (García Ruiz 2018). Examining international

3 criminal law is not a facile exercise as the legal and technical elaborations involved are

4 intricate even within the general frame in which such law is routinely practiced (in terms of

5 crimes against humankind). It is also a complex field because it is relatively young (developing

6 from the second half of the twentieth century onwards), growing, and still being tested. It is,

7 therefore, understandable that the even younger field of international environmental

8 criminal law is still in its early days of 'struggling for breath'.

Let us apply the idea of ecocide in the context of marine environments to two cases.

10 First, a recurrent catastrophe destroying Europe's largest salt water lagoon is occurring on

11 the coast of Mar Menor (Spain) with thousands of fish and crustaceans washed up dead on

12 beaches in the region due to lack of oxygen, unsustainable urban developments, farming and

13 pollution. This phenomenon has been observed for at least 20 years, although it attracted

14 public attention and scrutiny as a signal of collapse only recently as a result of a disaster taking

15 place in the area in October 2019, known as DANA or a 'cold front' - an event caused by

16 meteorological processes associated with the stratosphere-troposphere exchange which

17 trigger torrential rains and floods. This is not to attribute responsibility to nature, for, at most,

18 nature is also a victim of what is occurring. The causes seem to lie with the effects of intensive

19 and persistent processes of urbanisation, as well as soil fertilisation being carried out in the

20 region.

For a second case, let us consider the first-ever scientific report on the impact of

22 climate and environmental change in the Mediterranean basin-relying on previous research

23 carried out since 2015 by a group of over 80 scientists under German geographer Wolfgang

24 Cramer's guidance (see Cramer et al. 2018) - which has found that 'the region faces unequal 
1 distribution of resources, social instability, conflict and migration' (MedECC 2019:5). The

2 Balearic Islands, the northwest Ionian, the Aegean and Levantine Seas, have been identified

3 as the regions where fisheries and aquaculture are currently impacted most by destructive

4 practices, such as overfishing and coastal development (MedECC 2019: 8), and are also

5 experiencing a significant increase in sea surface temperature. Those causing and those

6 affected by these manifestations of ecocide at sea regularly become mired in debates about

7 what causes and consequences should be attributed to nature and what to other, artificial 8 sources.

Would these cases amount to illustrations of 'ecocide'? Undoubtedly, they meet the requirements of the definition offered by Higgins. That said, we are witnessing some

11 concerted efforts to treat our oceans as something other than (boundless) resources to be

12 pillaged in pursuit of perpetual growth and material wealth-and to reject the misguided

13 belief that we, as humans, have a right to dominion and sovereignty over the seas. We

14 conclude our essay with an example of ways in which the principles of sustainability, restoration and environmental justice can be applied in the context of modern fisheries.

\section{6. Turning the tide toward sustainability: The 'Almadraba' fishing method}

18 It can be suggestive to compare traditional fishing systems with modern industrial techniques

19 that result in overfishing of critically endangered species, such as the Atlantic bluefin tuna

20 (see generally Kolbert 2019). Historically, bluefin tuna, caught by the method of creating a labyrinth of nets (called the 'Almadraba') that the tuna swim through, has been a sustainable method of fishing without contributing to the decline of the species and has ancient roots dating back to the Phoenician-Punic-Roman period (Florido del Corral 2018). Today, harmful fishing practices (such as encircling the tuna with nets) and the global expansion of the tuna 
1 fishing industry, have contributed to overexploitation of tuna, endangering their survival

2 (García Vargas \& Florido del Corral 2010, Di Natale 2012, Brownell et al. 2019, Coulter et al.

3 2020). Traditional fishing systems have been slowly disregarded (Coulter et al. 2020) perhaps

4 because, as the EU acknowledged (Directorate-General for Internal Policies 2015), the

5 method of 'Almadraba' harvesting is more labour-intensive than any other fishing method.

6 Tuna caught by this method is increasingly appreciated by the market, although at present, it

7 is practiced only in Italy, Morocco, Portugal and Spain.

On account of the peculiar transit connection between Atlantic bluefin tuna and the

9 Mediterranean Sea, the broadest sense of the word 'Almadraba' or 'Madrague' in French, once widely translated as 'tuna fishing', remains solidly related to the place where the trapped

11 tunas struggle to escape from traps (Corriente 2008: 138). Despite its Arabic sound- derived

12 from Hispanic-Arabic (Drae) - the etymological origin remains controversial (see Soto Melgar

13 2014: 282). For instance, Italian terminology linked to this artisanal fishing technique includes

14 the descriptive expressions 'Mattanza' or 'Tonnara' (see Maggio 2000)-or 'camera della muerte' - that embodies the space in the net where the tuna is caught (Pitcher 2001: 603,

16 Emery 2010: 1). Regrettably, use of the traditional tuna trap barely survives in contemporary

17 fishing: only a few of these tonnare are seasonally active in insular zones in places such as

18 Sardinia and Sicily (Addis et al. 2016: 138) or in other, historically influential, zones in the Mediterranean belonging to Libya or Tunisia (Addis et al. 2012, Emery 2010). la Janda, Tarifa and Zahara de los Atunes, along with traps set in the Moroccan waters, but increasingly, the numbers in Morocco are few and fluctuating (Abid et al. 2012). This geographically restricted and shrinking space is the location of 'one of the most emblematic 
1 obliged to pass through it on their routes to the Mediterranean spawning grounds. The ritual

2 of the 'Almadraba' occurs twice a year. First, it is practiced with inward-bound traps 'when

3 the fish swim close to the Andalusian coast in the Straits of Gibraltar during their genetic

4 migration from the Atlantic to their breeding grounds in the Mediterranean Sea's warmer

5 waters' (Florido del Corral 2018:30). This is called the Almadraba de derecho. Second, it is

6 performed with outward-bound traps 'on the return journey [...] as the tuna again pass

7 through the Straits in search of the food on which they gorge in the Atlantic' (Florido del Corral

8 2018: 30), known as Almadraba de revés. At present, the technique that prevails over others

9 in the Spanish case is known as 'Almadraba de buche' (buche type). This takes place in coastal

10 waters fewer than 30 meters deep, where the shoals of bluefin tuna first enter the maze of

11 static nets (fixed to the seabed), then move ahead through the chambers until the crucial

12 moment in which they are eventually trapped inside and 'the fishermen decide to lift the

13 'copo' (terminal section) of the final chamber-into which the fish, in today's practice, are

14 forced by boats as well as frogmen-to the surface' (García Vargas \& Florido del Corral 2010:

15 207, Florido del Corral 2018).

16 In Portugal, fishing for bluefin tuna does not use any other method except employing

17 almadraba traps, mainly in the Algarve region, although tradition is also being changed by the

18 expansion of fishing activity to other species and by the growth of tourism (for an overview

19 see EU report 'The future of the Almadraba Sector' 2015, Lino et al. 2018).

The continuing use of this ancient method means a network of tuna traps is

21 maintained and hundreds of both direct and indirect employment positions are sustained.

22 Other kinds of tuna traps (called 'almadrabeta', 'moruna' or 'tonnarella') are also found along

23 the Mediterranean for catching smaller species of tuna like 'the bullet tuna (Auxis rochei) or

24 the skipjack Tuna (Katsuwonus pelamis)' (The future of the Almadraba Sector-Traditional 
1 Tuna Fishing Methods in the EU 2015: 16), as well as sand smelt (Atherina boyeri), squid

2 (Teuthida) or greater amberjack (Seriola dumerili).

The value of this approach as a sustainable method is why it is of interest here and this could be tested in the area of La Azohía (Cartagena), for instance, by examining the performance of the isolated Almadraba fishing fleet located in the South of Spain that has been regularly employed between February and July since 1946. Recently, this community has developed communications management strategies using social network websites such as Instagram (https://www.instagram.com/almadraba la azohia/?hl=es) and Twitter

9 (https://twitter.com/AAzohia) to catch the attention and connect with the increasing international interest in Atlantic bluefin tuna.

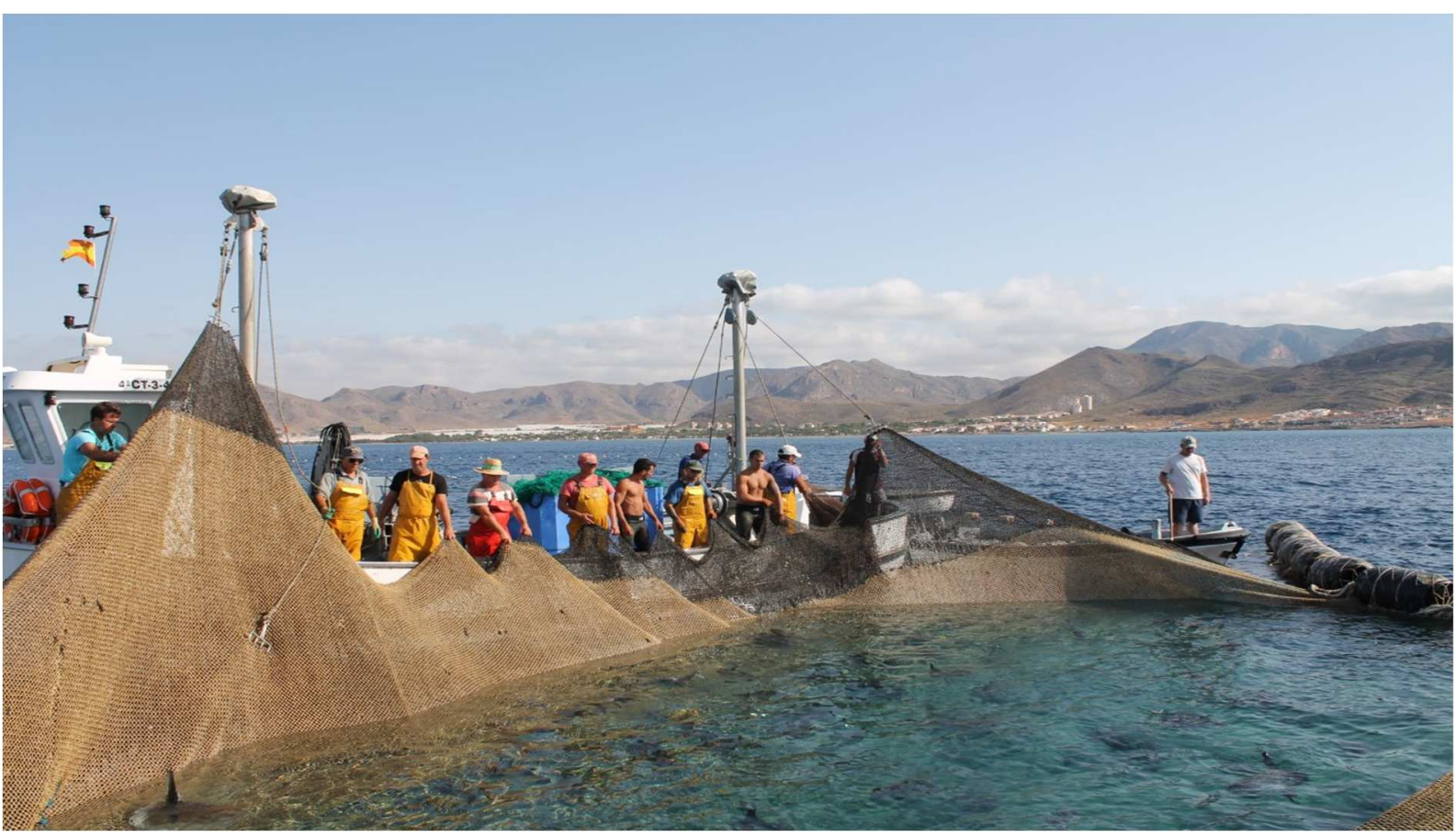

Fig.1 Lifting of the trap (the 'leva') at the Almadraba in La Azohía (Spain) Source: Photograph by Mercedes García

In terms of economics, hundreds of families depend on the Almadraba, an important source of employment in the fishery sphere and the 'subsidiary' industries of salting and canning (García Vargas \& Florido del Corral 2010, The future of the Almadraba Sector- 
1 Traditional Tuna Fishing Methods in the EU 2015). In terms of the environment, this method

2 of fishing offers several advantages.

First, it is a seasonal system based on the migration of the shoals of bluefin tuna both

in late spring across the Strait of Gibraltar to reach warmer waters and to mislead their natural predators-killer whales-and in the late summer (trophic migration) on their return. They search for proper 'hatching areas (gametic migration) where they can find nutrients for their offspring and where the temperature and salinity of the water favours the development of young fish' (García Vargas \& Florido del Corral 2010: 206). In this light, it has already been pointed out that tuna traps modify neither the habitual tuna migration routes, nor their life cycle, growth, or reproduction, nor do they cause any harmful effects on the seabed or the pelagic ecosystem (The future of the Almadraba Sector-Traditional Tuna Fishing Methods in the EU 2015: 55) ${ }^{8}$. Second, the method is founded upon passive selective fishing methods: there is no use of methods to drive, lure or attract the tuna but only use of 'passive gear' which may be anchored to the seabed. Regardless of how this method is operated, it is far less destructive than bottom trawling bycatch methods. catch operation because this arrangement of nets is usually close to land. Moreover, a legal framework and a ban on additional fishing are set every year in order to protect stocks against

\footnotetext{
${ }^{8}$ In terms of biology, studies note that migrations get longer as the size of tuna increases and 'In order to spawn the tunas emigrate in great shoals (Arena 1979) that choose ...' (Cort \& Abaunza 2019: 8) areas of ecological and environmental abundance. Marine health and sustainability in these areas, and the status of the Mediterranean bluefin tuna population, need monitoring and it has been noted that the traps do serve as a form of basic scientific observatory (Cort \& Abaunza 2019: 66). To collect more detailed and comparative data will require investment in additional systems, given that the closure of the Tunisian and Libyan traps in recent years means the loss of these sources of observation (Addis et al. 2012: 140).
} 
1 of nets in ways that allocate and guarantee historical entitlements. Equally important is the

2 supervision of the quota and their minimum size, aiming to allow the tuna to reach sexual

3 maturity and to reproduce harmoniously 9. Fourth, use of tuna traps has never led to the collapse of stocks and or exerted any

5 influence on the local hydrological dynamics. From 1998 to 2008, however, both 'capitalist

6 fishing operations, as much as the high level of underreporting, misreporting, un-reporting

7 catch, caused a catastrophic situation' (Longo \& Clark 2012, The future of the Almadraba

8 Sector-Traditional Tuna Fishing Methods in the EU 2015: 50).

This is an example of an approach to living with the sea and benefiting from fishing that combines the importance of cultural heritage with the modern concept of sustainability.

7. Conclusion

As Cohen and colleagues (2019:5) observe, '[t]o date oceans and coasts have not been

14 well accounted for in the calculation or conceptualization of planetary boundaries' and in devising policies for the future-whether regarding food or extraction-these must be sustainable and 'navigate the space between the environmental ceiling or "planetary

17 boundaries" [...] and a "social foundation"'. The complexity of these ecosystems must be understood and emphasized and orthodox international criminal law must do more to recognize and respond to the implications of the growing 'burden on ocean ecosystems'

20 (Blasiak 2020) and the dangers of entering an era of unsustainability. Adoption of a law of ecocide, as well as related forms of inclusive governance that involve those whose livelihoods

\footnotetext{
${ }^{9}$ As Minder (2015) points out, however, 'the almadraba fishermen say their method has been unfairly punished for the past fishing excesses of others, not least because in their method, only adult tuna-weighing on average around 440 pounds each-are trapped and lifted in their large mesh nets'.
} 
1 depend on the sea and the land (see Leschin-Hoar 2016), could build on evidence that it is

2 possible to 'successfully manage the tensions between national and regional economic

3 growth, local livelihood resilience, and food and nutritional security for those most in need

4 (Jentoft \& Chuenpagdee, 2015)' (Cohen et al. 2019: 6). Cultural and socioeconomic strata are

5 essential in the way of living ascribed to the Almadraba. The 'Almadraba' symbolises the

6 ability of maritime societies to turn a natural phenomenon-recurring migrations of tunas

7 and their approach to the coasts under certain environmental circumstances-into a

8 sociocultural construction that celebrates and embraces sustainability (Florido del Corral

9 2005: 2); this example of one of the first industrial activities in history (Di Natale 2018: 2944)

10 deserves more consideration and adoption. This is an ethical approach, realistic but

11 principled. It is realistic in acknowledging the pressures exerted by calls for economic growth

12 and by globalised demand and supply, but ethical in prioritising the need to remember to

13 defend access, locality and equity.

14 


\section{Literature Cited}

Abid N, Benchoucha S, Belcaid S, Lamtai A \& El Fanichi C (2012) Moroccan tuna traps: history and current situation, Collect. Vol. Sci. Pap. ICCAT, 67(1): 124-138.

Addis P, Secci M, Locci I, Cau A, Sabatini A (2012) Analysis of Atlantic bluefin tuna catches from the last Tonnara in the Mediterranean Sea: 1993-2010, Fisheries Research (127-128): 133-41.

Addis P, Secci M, Biancacci C, Loddo D, Cuccu D, Palmas F, Sabatini A (2016) Reproductive status of Atlantic bluefin tuna, Thunnus thynnus, during migration off the coast of Sardinia (western Mediterranean), Fisheries Research (181): 137-147.

Agnew D-J, Pearce J, Pramod G, Peatman T, Watson R, Beddington J-R, Pitcher T-J (2009) Estimating the worldwide extent of illegal fishing. PLoS ONE 4(2) [e4570]: 1-8. https://doi.org/10.1371/journal.pone.0004570

Baucells L \& Petit B (2013) Possibilities and limits of environmental criminal protection. Reflections on the Erika and Prestige cases (or how an organized irresponsibility system carries on). InDret/Revista Para el Análisis del Derecho 3/2013. Retrieved from: https://ddd.uab.cat/record/196942

Bearzi G (2020) Marine biology in a violated planet: from science to conscience. Ethics in Science and Environmental Politics. DOI: https://doi.org/10.3354/esep00189.

Belhabib D \& Le Billon P (2020) Editorial: Illegal Fishing as a Trans-National Crime. Frontiers in Marine Science 7 (19 March): 162. doi: 10.3389/fmars.2020.00162.

Bennett NJ, Cisneros-Montemayor AM, Blythe J et al. (2019) Towards a sustainable and equitable blue economy. Nature Sustainability 2, 991-993, https://doi.org/10.1038/s41893019-0404-1

Berat $L$ (1993) Defending the right to a healthy environment: towards a crime of geocide in international law. Boston University International Law Journal, 11, 327-348.

Berg J, Geoffroy M, Daase M, Cottier F, Priou P, Cohen JH, Johnsen G, McKee D, Kostakis I, Renaud PE, Vogedes D, Anderson P, Last KS, Gauthier S (2020) Artificial light during the polar night disrupts Arctic fish and zooplankton behaviour down to $200 \mathrm{~m}$ depth. Communications Biology 3: 1-8. https://doi.org/10.1038/s42003-020-0807-6

Blasiak R (2020) Blue Acceleration: our dash for ocean resources mirrors what we've already done to the land. The Conversation, January 24, https://theconversation.com/blueacceleration-our-dash-for-ocean-resources-mirrors-what-weve-already-done-to-the-land$\underline{130264}$

Bondaroff T-N, Van Der Werf W, Reitano T (2015) 'The Illegal Fishing and Organized Crime Nexus: Illegal Fishing as Transnational Organized Crime'. The Global Initiative Against 
Transnational Organized Crime (April) 84, Geneva, https://globalinitiative.net/wp-

Boyle A (2012) Human Rights and the Environment: Where Next? Eur. J. Int. Law 23(3): 613642.

6

Brisman A (2003) A Less Tragic Commons?: Using Harvester and Processor Quotas to Address Crab Overfishing. Seattle University Law Review 26(4): 929-978.

Brisman A (2011) United Nations Conference on Law of the Sea. In: Chatterjee D (ed) Encyclopedia of Global Justice, Vol.2. Springer, Heidelberg, Germany, p 1103-04.

Brisman A (2013) Not a Bedtime Story: Climate Change, Neoliberalism, and the Future of the Arctic. Michigan State International Law Review 22(1): 241-89.

Brisman A (2014a) Environmental and human rights. In: Bruinsma G, Weisburd D (eds) Encyclopedia of Criminology and Criminal Justice, Springer Verlag, New York, p 1344-1353.

Brisman A (2014b) Of Theory and Meaning in Green Criminology. International Journal for Crime, Justice and Social Democracy 3(2), 21-34.

Brisman A \& South N (2018) Autosarcophagy in the Anthropocene and the obscenity of an epoch. In: Holley C, Shearing C (eds) Criminology and the Anthropocene. Routledge, London and New York, p 25-49.

Brisman A \& South N (2019a) A criminology of extinction: Biodiversity, extreme consumption and the vanity of species resurrection. European Journal of Criminology. First published 28 February 2019, https://doi.org/10.1177/1477370819828307

Brisman A \& South N (2019b) Green Criminology and Environmental Crimes and Harms. Sociology Compass 13(1); e12650. https://doi.org/10.1111/soc4.12650

Brisman A \& South N (eds) (2020) Routledge International Handbook of Green Criminology $2^{\text {nd }}$ ed. Routledge, Abingdon, Oxon, UK.

Brisman A, McClanahan B, South N, Walters R (2018) Water, Crime and Security in the TwentyFirst Century: Too dirty, too little, too much. Palgrave Macmillan, London.

Brown J \& Macfayden G (2007) Ghost fishing in European waters: Impacts and management response. Marine Policy 31(4) [July]: 488-504.

Brownell Jr RL, Reeves RR, Read AJ, Smith BD, Thomas PO et al. (2019) REVIEW: Bycatch in gillnet fisheries threatens Critically Endangered small cetaceans and other aquatic megafauna. ESR Special: Marine vertebrate bycatch: problems and solutions. Endang Species Res 40: 285-296. doi: https://doi.org/10.3354/esr00994 
1 Bueger C (2020) Mauritius oil spill: potential government failures should be investigated -

2 expert. The Conversation, August 18, https://theconversation.com/mauritius-oil-spill-

3 potential-government-failures-should-be-investigated-expert-144622

Bueger C \& Edmunds T (2020) Blue crime: Conceptualising transnational organised crime at sea. Marine Police (119): 104067.

Chivers CJ (2007) Eyeing Future Wealth, Russians Plant the Flag on the Arctic Seabed, Below the Polar Cap. The New York Times. 3 Aug: A8. Published online as "Russians Plant Flag on the Arctic Seabed," 3 Aug., http://www.nytimes.com/2007/08/03/world/europe/03arctic.html

Cohen MA (2018) The Commission for Environmental Cooperation: Working on Oceans and Mangroves. In: Sosa-Nunez G (ed) Widening the Scope of Environmental Policies in North America: Toward Blue Approaches. Palgrave Macmillan, Cham, p 77-91.

Cohen P, Allison E, Andrew N, Cinner J, Evans L, Fabinyi M, Garces L, Hall S, Hicks C, Hughes T, Jentoff S, Mills D, Masu R, Mbaru E, Ratner B (2019) Securing a just space for small-scale fisheries in the blue economy. Frontiers in Marine Science 6(April): 171.

Collins VE (2015) Somalis Fight Back: Environmental Degradation and the Somali Pirate._In: Brisman, A, South N, White R (eds) Environmental Crime and Social Conflict: Contemporary and Emerging Issues. Ashgate, Surrey, UK, p 153-173.

Corriente F (2008) Dictionary of Arabic and Allied Loanwords. Spanish, Portuguese, Catalan, Galician and Kindred Dialects. Leiden-Boston: Brill.

Cort JL \& Abaunza P (2019) The Bluefin Tuna Fishery in the Bay of Biscay. Its Relationship with the Crisis of Catches of Large Specimens in the East Atlantic Fisheries from the 1960s. Series: SpringerBriefs in Biology. Springer International Publishing.

Costello C, Cao L, Gelcich S, Cisneros-Mata MA, Free CM, Froehlich HE, Golden CD, Ishimura G, Maler J, Macadam-Somer I, Mangin T, Melnychuk MC, Miyahara M, de Moor CL, Naylor R, Nøstbakken L, Ojea E, O'Reilly E, Parma AM, Plantinga AJ, Thilsted SH \& Lubchenco J (2020) The future of food from the sea. Nature, Published 19 August 2020, https://www.nature.com/articles/s41586-020-2616-y

Coulter A, Cashion T, Cisneros-Montemayor A-M, Popov S, Tsui G, Le Manach F, Schiller L, Palomares M-L, Zeller D, Pauly D (2020) Using harmonized historical catch data to infer the expansion of global tuna fisheries. Fisheries Research 221 (January), 105379.

Cramer W, Guiot J, Fader M, Garrabou J, Gatusso J-P, Iglesias A, Lange M, Lionello P, Llasat M, Paz S, Peñuelas J, Snoussi M, Toreti A, Tsimplis MN, Xoplaki E (2018) Climate change and interconnected risks to sustainable development in the Mediterranean. Nature Climate Change 8: 972-980.

Dayton PK, Thrush SF, Agardy MT, Hofman RJ (1995) Environmental effects of marine fishing. Aquatic Conservation: Marine and Freshwater Ecosystems 5(3): 205-232. 
1 Denton GL \& Harris JR (2019) The impact of illegal fishing on maritime piracy: evidence from

2 West Africa. Stud. Confl. Terror. doi: 10.1080/1057610X.2019.1594660.

3

Diccionario de la Real Academia Española. 'Almadraba'. In Diccionario de la Lengua Española, 23. a ed. [23.3 version], https://dle.rae.es/almadraba

Díez-Ripollés JL (2019) Rationality in Criminal Law Making. Rational Decision Making in a Complex Socio-Legislative Process. In: Oliver-Lalana D (ed) Conceptions and Misconceptions of Legislation, Cham, Springer, p 51-80.

Di Natale A (2012) An Iconography of Tuna Traps. Essential Information for the Understanding of the Technological Evolution of this Ancient Fishery. Collect. Vol. Sci. Pap. ICCAT 67(1): 3374.

Di Natale A (2018) An Updated Bibliography on Bluefin Tuna Trap Fishery. Collect. Vol. Sci. Pap. ICCAT 74(6): 2942-3036.

Directorate-General for Internal Policies (2015) The future of the Almadraba Sector Traditional Tuna Fishing Methods in the EU, Policy Department B: Structural and Cohesion Policies. European Parliament's Committee on Fisheries, https://www.europarl.europa.eu/RegData/etudes/STUD/2015/540367/IPOL STU(2015)540 367 EN.pdf

Dudley N (ed) (2008) Guidelines for Applying Protected Area Management Categories. Gland, Switzerland: IUCN. WITH Stolton S, Shadie P, Dudley, N (2013) IUCN WCPA Best Practice Guidance on Recognising Protected Areas and Assigning Management Categories and Governance Types, Best Practice Protected Area Guidelines Series No. 21, Gland, Switzerland: IUCN, https://portals.iucn.org/library/sites/library/files/documents/PAG-021.pdf

Emery K B (2010) Tonnare in Italy: Science, History and Culture of Sardinian Tuna Fishing, California Italian Studies, 1(1), https://escholarship.org/uc/item/2nm2b772

Europol (2019a) Marine pollution: thousands of serious offences exposed in global operation Press $\quad$ Release. $16 \quad$ December 2019, https://www.europol.europa.eu/newsroom/news/marine-pollution-thousands-of-seriousoffences-exposed-in-global-operation

Europol (2019b) Over 5 tonnes of smuggled glass eels seized in Europe this year. Press Release, 6 November, https://www.europol.europa.eu/newsroom/news/over-5-tonnes-ofsmuggled-glass-eels-seized-in-europe-year

Fajardo del Castillo T (2015) Organised Crime and Environmental Crime: Analysis of EU Legal Instruments. Study in the framework of the EFFACE research project, Granada: University of Granada.

Falk RA (1973) Environmental warfare and ecocide - facts, appraisal, and proposals. In T. Marek (Ed.), Bulletin of peace proposals 1973 (Vol. 1) Oslo: Universitersforlaget, 80-96. 
1 Florido del Corral D (2018) What it takes to be the captain of a Tuna Trap: Practice, Knowledge 2 and skills for the sustainability of an age-old mode of fishing. In: Bermúdez-Figueroa E, Roca 3 B (ed) Andalusia: History, Society and Diversity. Nova Science, Hauppauge, New York, p 29455.

5

6

Florido del Corral D (2005) Evolución histórica y cultural de las almadrabas en el litoral atlántico meridional (siglos XVI-XX). Quaderns Blaus (13) Girona: Museu de la Pesca.

Frank V (2005) Consequences of the Prestige Sinking for European and International Law. The International Journal of Marine and Coastal Law 20(1):1-64.

Fuentes Osorio JL, Fajardo del Castillo T, Faria R, Sousa P, Quintas J, Cruz JN (2020) Estudio sobre el carácter disuasorio, efectivo y proporcional de las sanciones penales impuestas en España y Portugal en delitos contra el medio ambiente y su adecuación a la Directiva 2008/99/EC sobre protección del medio ambiente a través del Derecho penal. Universidad de Granada - Universidad de Jaén - Universidade do Porto, https://guardianes.seo.org/download/estudio-sobre-el-caracter-disuasorio-efectivo-yproporcional-de-las-sanciones-penales-impuestas-en-espana-y-portugal-en-delitos-contrael-medio-ambiente-y-su-adecuacion-a-la-directiva-2008-99-ec-sobr/

García Ruiz A (2014) Dos caras de un mismo tipo. A propósito del delito ecológico en dos supuestos: caso Prestige y caso de la pianista ruidosa (desproporción en cuanto al resultado fáctico, víctimas y bien jurídico protegido). Revista La Ley Penal 109(11): 82-89.

García Ruiz A (2017) Green Criminology. El ruido: Un intruso en el Derecho penal medioambiental. Montevideo - Buenos Aires, BdeF.

García Ruiz A (2018) Del Ecocidio y los procesos migratorios a la opacidad de la victimización ecológica. Revista Electrónica de Ciencia Penal y Criminología 20-11 (1-44), http://criminet.ugr.es/recpc/20/recpc20-11.pdf

García Vargas E \& Florido del Corral D (2010) The Origin and Development of Tuna Fishing Nets (Almadrabas). In: Bekker-Nielsen T, Bernal Casasola D (eds) Ancient Nets and Fishing Gear, Proceedings of the International Workshop on 'Nets and Fishing Gear in Classical Antiquity: A First Approach. Cadiz, November 2007, Universidad de Cádiz and Aarhus University Press, 205-227.

Gauger A, Rabatel-Fernel MP, Kulbicki L, Short D, Higgins P (2012) Ecocide is the missing 5th Crime Against Peace. The Ecocide Project, Human Rights Consortium, School of Advanced Study, University of London, http://sas-space.sas.ac.uk/4686/

Gibbens S (2020) As the Arctic warms, light pollution may pose a new threat to marine life. National Geographic. 5 March, https://www.nationalgeographic.co.uk/environment-andconservation/2020/03/arctic-warms-light-pollution-may-pose-new-threat-marine-life 
1 Giovannini N, Melica L, Cukani E, Giannotta M, Zingoni M (2013) Addressing Environmental

2 Crimes and Marine Pollution in the EU. Legal guidelines and case studies. Droit au Droit,

3 Brussels, https://www.dadinternational.org/images/PDF/Guide-Web.pdf

4

5

6

Gore M L, Braszak P, Brown J et al. (2019) Transnational environmental crime threatens sustainable development. Nature Sustainability 2:784-786, https://doi.org/10.1038/S41893019-0363-6

Gray MA (1996) The international crime of ecocide. California Western International Law Journal 26, 215-271.

Greife M \& Stretesky, PB (2013) Crude laws: Treadmill of production and state variations in civil and criminal liability for oil discharges in navigable waters. In: South N, Brisman, A (eds) Routledge International Handbook of Green Criminology. Abingdon, Oxon, UK, Routledge, $p$ 150-166.

Greenberg P (2010) Tuna's End. The New York Times Magazine. 27 June: 28-37, https://www.nytimes.com/2010/06/27/magazine/27Tuna-t.html

Haenlein C (2017) Below the Surface How Illegal, Unreported and Unregulated Fishing Threatens our Security. Occasional paper July 2017, Royal United Services Institute for Defence and Security Studies, https://rusi.org/sites/default/files/201707 rusi below the surface haenlein.pdf

Hardin G (1968) The tragedy of the commons. Science 162:1243-1248.

Higgins P, Short D, South N (2013) Protecting the planet: a proposal for a law of ecocide. Crime, Law and Social Change 59(3): 251-266.

Higgins P (2015) Eradicating Ecocide. Exposing the corporate and political practices destroying the planet and proposing the laws to eradicate ecocide, $2^{\text {nd }}$ ed. Shepheard-Walwyn, London.

Interpol (2019) Operation 30 Days at Sea. Tackling Marine Pollution Crime - Final Operational Report. 9 July, https://www.interpol.int/Crimes/Environmental-crime/Pollution-crime

Jentoft S \& Chuenpagdee, R (2015) Interactive Governance for Small-Scale Fisheries: Global Reflections. Springer, Dordrecht. doi: 10.1007/978-3-319-17034-3.

Jouffray J-N, Blasiak R, Norström A, Österblom H, Nyström H (2020) The Blue Acceleration: The Trajectory of Human Expansion into the Ocean. One Earth, Perspective 2(1): 43-54. doi: /10.1016/j.oneear.2019.12.01.

Junker K (ed) (2019) Environmental Law across Cultures: Comparisons for Legal Practice Routledge, London.

Klein N (2019) On Fire: The Burning Case for a Green New Deal. Allen Lane, London. 
Kolbert E (2019) Last Chances. The New Yorker, 20 May: 23-24.

Laffoley D, Baxter JM, Day JC, Wenzel L, Bueno P, Zischka K (2019) Marine Protected Areas. In: Sheppard C (ed) World Seas: An Environmental Evaluation Volume III: Ecological Issues and Environmental Impacts, $2^{\text {nd }}$ ed. Elsevier, London, p 549-569.

Lavaniegos BE (2018) Consequences of Climate Change on the Oceans. In: Sosa-Nunez G (ed) Widening the Scope of Environmental Policies in North America: Toward Blue Approaches. Palgrave Macmillan, Cham, p 95-110.

Leschin-Hoar C (2016) Whales, Sea Turtles, Seals: The Unintended Catch Of Abandoned Fishing Gear. National Public Radio. 28 September, https://www.npr.org/sections/thesalt/2016/09/28/495777033/whales-sea-turtles-sealsthe-unintended-catch-of-abandoned-fishing-gear

Levin P \& Poe M (eds) (2017) Conservation for the Anthropocene Ocean: Interdisciplinary Science in Support of Nature and People. Academic Press, Cambridge, Massachusetts.

Lino PG, Rosa D, Coelho R (2018) Update on the bluefin tuna catches from the tuna trap fishery off southern Portugal (ne Atlantic) between 1998 and 2016, with a preliminary CPUE standardization. Collect. Vol. Sci. Pap. ICCAT 74(6): 2719-2733.

Longo SB \& Clark B (2012) The Commodification of Bluefin Tuna: The Historical Transformation of the Mediterranean. Fishery Journal of Agrarian Change, Vol. 12 Nos. 2 and 3, April and July: 204-226.

Lubchenco J \& Gaines, S (2019) A new narrative for the ocean. Science 364.

Lynch MJ, Long MA, Stretesky PB, Barrett KL (2017) Green Criminology: Crime, Justice, and the Environment. University of California Press, Berkeley, California.

Maggio T (2000) Mattanza. Love and Death in the Sea of Sicily. Counterpoint.

MedECC (2019) Risks associated to climate and environmental changes in the Mediterranean region. A preliminary assessment by the MedECC Network Science-policy interface 2019, https://www.medecc.org/wp-content/uploads/2018/12/MedECC-Booklet EN WEB.pdf

Developed by W. Cramer (IMBE, CNRS; MedECC), J. Guiot (CEREGE, CNRS; MedECC) and K. Marini (MedECC), and based on: Cramer W, Guiot J, Fader M, Garrabou J, Gattuso J-P, Iglesias A, Lange MA, Lionello P, Lla-sat MC, Paz S, Peñuelas J, Snoussi M, Toreti A, Tsimplis MN, Xoplaki E (2018) Climate change and interconnected risks to sustainable development in the Mediterranean. Nature Climate Change 8, 972-980, doi: 10.1038/ s41558-018-0299-2.

Minder R (2015). Spanish Tuna Fishing Melds to Japan's Taste, Reshaping a 3,000-Year-Old Technique. The New York Times, June 6, 2015, https://www.nytimes.com/2015/06/07/world/europe/spanish-tuna-fishing-melds-tojapans-taste-endangering-a-3000-year-old-technique.html 
Nengye L (2016) Can the Polar Code Save the Arctic? The American Society of International Law. Insights 20(7) [22 March], https://www.asil.org/insights/volume/20/issue/7/can-polarcode-save-arctic

Nurse A (2015) Policing Wildlife: Perspectives on the Enforcement of Wildlife Legislation. Palgrave Macmillan, Basingstoke, Hampshire, UK.

Orbach M (2003) Fourth Annual Roger Revelle Lecture-Beyond the freedom of the seas: Ocean policy for the third millennium. Oceanography 16(1): 20-29. https://doi.org/10.5670/oceanog.2003.55

Parfitt T (2007) Russia plants flag on North Pole seabed. The Guardian. 2 August, https://www.theguardian.com/world/2007/aug/02/russia.arctic

Paulson N (2018) An emergent 'blue criminology'? Review of a new critical criminology book on water. Critical Criminology: An International Journal. Published: 12 September 2018. https://doi.org/10.1007/s10612-018-9410-2

Pauly D \& Zeller D (2016) Catch reconstructions reveal that global marine fisheries catches are higher than reported and declining. Nature Communications 7, Article: 10244 https://www.nature.com/articles/ncomms10244

Penela-Arenaz M, Bellas J, Vázquez E (2009) Chapter Five: Effects of the Prestige Oil Spill on the Biota of NW Spain: 5 Years of Learning. Advances in Marine Biology 56: 365-396.

Pierre-Louis K \& Popovich N (2019) Ocean Heat Waves Are Threatening Marine Life. The New York Times. 5 March: A8. Published online as "Ocean Heat Waves Are Threatening Marine Life" on 4 March 2019, https://www.nytimes.com/2019/03/04/climate/marine-heatwaves.html

Pitcher TJ (2001) Fisheries managed to rebuild ecosystems? Reconstructing the past to salvage the future. Ecological Applications 11(2): 601-617.

Reuters (2007) Russia plants flag on Arctic floor. CNN. 4 August, https://edition.cnn.com/2007/WORLD/europe/08/02/arctic.sub.reut/index.html

Rodríguez-Rodríguez D (2019) Marine Protected Areas: Attempting the Sustainability of the Seas. In: Sheppard C (ed) World Seas: An Environmental Evaluation Volume III: Ecological Issues and Environmental Impacts, $2^{\text {nd }}$ ed. Elsevier, London, p 475-489.

Ruggiero V (2013) The Crimes of the Economy. A criminological analysis of economic thought. Routledge, New York.

Ruggiero V \& South N (2010) Green Criminology and Dirty Collar Crime. Critical Criminology: An International Journal 18(4): 251-262.

Russ GR \& Zeller DC (2003) From Mare Liberum to Mare Reservarum. Marine Policy 27:75-78. 
Sands P, Peel J, Fabra A, Mackenzie R (2018) Principles of International Environmental Law.

2 Cambridge University Press, Cambridge.

3

Schiffman HS (2018) The Law of the Sea and Other Instruments of International Law as a Framework for Environmental Conservation in North American Waters. In: Sosa-Nunez G (ed) Widening the Scope of Environmental Policies in North America: Toward Blue Approaches. Palgrave Macmillan, Cham, p 57-76.

Sergi A \& South N (2016) 'Earth, Water, Air, and Fire': Environmental Crimes, Mafia Power and Political Negligence in Calabria. In: Antonopolous G (ed) Illegal Entrepreneurship, Organized Crime and Social Control, Essays in Honor of Professor Dick Hobbs. Springer, Cham, p 85-100.

Sheppard C (ed) (2019) World Seas: An Environmental Evaluation Volume III: Ecological Issues and Environmental Impacts, $2^{\text {nd }}$ ed. Elsevier, London.

Smale DA, Wernberg T, Oliver ECJ, Thomsen M, Harvey BP, Straub SC, Burrows MT, Alexander LV, Benthuysen JA, Donat MG, Feng M, Hobday AJ, Holbrook NJ, Perkins-Kirkpatrick SE, Scannell HA, Gupta AS, Payne BL, Moore PJ (2019) Marine heatwaves threaten global biodiversity and the provision of ecosystem services, Nature Climate Change 9(April): 306312.

Sosa-Nunez G (2018) Introduction: Beyond Brown and Green Policies in North America. In: Sosa-Nunez G (ed) Widening de Scope of Environmental Policies in North America. Towards Blue Approaches. Palgrave Macmillan, Cham, p 1-12.

Soto Melgar M (2014) Estudio onomasiológico y semasiológico de la terminología almadrabera gaditana. In Clara Grande, Leire Martín, Soraya Salicio (Coords.), Con una letra joven. Avances en el estudio de la Historiografía e Historia de la Lengua Española. Aquilafuente 205-Ediciones Universidad de Salamanca, p 281-288.

South N (1998) A green field for criminology?: a proposal for a perspective. Theoretical Criminology 2(2): 211-234.

South N (2014) Green Criminology: Reflections, Connections, Horizons. International Journal for Crime, Justice and Social Democracy 3(2): 5-20.

South N (2016) Free trade agreements, private courts and environmental exploitation: disconnected policies, denials and moral disengagement. International Journal for Crime, Justice and Social Democracy 5(4): 45-59.

Staff C (2020) Whales entangled in nets put spotlight on Med dangers to marine mammals. Gibraltar Chronicle, July 22, 2020, https://www.chronicle.gi/whales-entangled-in-nets-putspotlight-on-med-dangers-to-marine-mammals/ 
1 Sun Z \& Beckman R (2018) The development of the Polar Code and challenges to its 2 implementation. In: Zou K (ed) Global Commons and the Law of the Sea, Series: Maritime 3 Cooperation in East Asia, vol 5, Brill | Nijhoff, Leiden, 303-325.

Taylor M (2019) Campaign to save oceans maps out global network of sanctuaries. The

UNEP-WCMC \& IUCN (2020) Protected Planet: The World Database on Protected Areas (WDPA) [On-line]. January, UNEP-WCMC, Cambridge, UK, www.protectedplanet.net

UNODC (2011) Transnational Organized Crime in the Fishing Industry. Focus on: Trafficking in Persons, Smuggling of Migrants, Illicit Drugs Trafficking. United Nations Office on Drugs and Crime, Vienna.

UNODC (2017) Fisheries Crime. United Nations Office on Drugs and Crime, Vienna.

Vidas D (2015) The Earth in the Anthropocene - and the World in the Holocene? European Society of International Law ESIL Reflections August 24, 4(6): 1-7, https://esil-sedi.eu/fr/esilreflection-the-earth-in-the-anthropocene-and-the-world-in-the-holocene/

Vrancken P, Witbooi E, Glazewski J (2019) Introduction and overview: transnational organised fisheries crime Mar. Policy 105: 116-122. doi: 10.1016/j.marpol.2018.12.016.

WWF (2020) Mangrove forests are one of the world's most threatened tropical ecosystems, https://wwf.panda.org/our work/oceans/coasts/mangroves/mangrove threats/

Walters R (2014) Organized Crime and the Environment. In: Bruinsma G., Weisburd D. (eds) Encyclopedia of Criminology and Criminal Justice, Springer, New York.

White R (2017) Carbon economics and transnational resistance to ecocide. In: Hall M, Maher J, Nurse G, Potter G, South N, Wyatt T (eds) Greening Criminology in the $21^{\text {st }}$ Century. Contemporary Debates and Future Directions in the Study of Environmental Harm, Routledge, New York, p 11-24.

Zalasiewicz J, Waters CN, Williams M, Summerhayes C (eds) (2019) The Anthropocene as a Geological Time Unit. A Guide to the Scientific Evidence and Current Debate. University Press, Cambridge. 